\title{
HUBUNGAN ANTARA PERHATIAN ORANG TUA TERHADAP PRESTASI BELAJAR SISWA DALAM BIDANG STUDI GEOGRAFI KELAS VIII SMP AL - IRSYAD KOTA TERNATE
}

\author{
Fitri Annisa Djafar ${ }^{1}$, Hernita Pasongli ${ }^{2}$, Tamrin Robo ${ }^{3}$, A.R Tolangara ${ }^{4}$ \\ ${ }^{1,2,3,4}$ Program Studi Pendidikan Geografi, Jurusan IPS \\ Fakultas Keguruan dan Ilmu Pendidikan (FKIP), Unkhair \\ E-mail: mukhtarnita@gmail.com ${ }^{3}$
}

\begin{abstract}
Abstrak
Keluarga menjadi lingkungan pendidikan yang paling mendasar, pertama dan utama, karena di sinilah anak mengenal dunia pertama kalinya, lingkungan di luar dirinya. Kemudian disebut lingkungan pendidikan yang utama bagi anak, karena keberhasilan pendidikan anak dalam keluarga ketika anak berada dalam usia dini yang dikenal sebagai usia emas (golden age), akan sangat berpengaruh pada keberhasilan pendidikan periode perkembangan anak berikutnya. Tujuan dari penelitian ini yaitu untuk mengetahui hubungan antara perhatian orang tua terhadap prestasi belajar siswa dalam bidang studi geografi kelas VIII SMP Al - Irsyad Kota Ternate. Jenis penelitian ini adalah penelitian kuantitatif deskriptif, sampel dalam penelitian ini adalah siswa kelas VIII SMP AL-Irsyad Kota Ternate yang berjumlah 33 orang siswa. Teknik dalam pengumpulan data menggunakan kuisioner. Hasil penelitian menunjukan bahwa terdapat hubungan yang positif antara perhatian orang tua terhadap prestasi belajar siswa dalam bidang studi geografi kelas VIII SMP Al-Irsyad Kota Ternate, besar hubungan perhatian orang tua dan prestasi belajar adalah $89 \%$. Semakin tinggi perhatian orang tua maka akan semakin tinggi pula prestasi belajar siswa. Hal ini berarti bentuk-bentuk perhatian orang tua seperti pemberian bimbingan dan nasehat, pengawasan terhadap anak, pemberian penghargaan dan hukuman, pemenuhan fasilitas belajar, penciptaan suasana rumah yang tenang, nyaman, dan tenteram serta pemberian keteladanan, pengarahan, dan dukungan dapat meningkatkan prestasi belajar siswa.
\end{abstract}

Kata Kunci : Perhatian Orang Tua, Prestasi Belajar.

\section{Pendahuluan}

Pendidikan merupakan kebutuhan dasar setiap manusia. Dengan pendidikan, manusia akan mampu membangun masa depan dan peradabannya. Masa depan yang cerah dan peradaban yang maju tidak akan dapat dicapai tanpa adanya pendidikan. Pendidikan sebagai usaha yang strategis dan paling mendasar dalam menyiapkan sumberdaya manusia yang berkualitas.
Pendidikan merupakan usaha sadar dan terencana untuk mewujudkan suasana belajar dan proses pembelajaran agar peserta didik secara aktif mengembangkan potensi dirinya untuk memiliki kekuatan spritual keagamaan, pengendalian diri, kepribadian, kecerdasan, akhlak mulia, serta keterampilan yang diperlukan oleh dirinya sendiri, masyrakat, bangsa dan negara (Undang - 
Undang Republik Indonesia Nomor 20 Tahun 2003).

Dalam mencapai tujuan pendidikan tersebut diperlukan kerja sama berbagai pihak. Dalam paradigma baru pendidikan Indonesia dikenal istilah trilogi pendidikan yaitu pendidikan keluarga, sekolah, dan masyarakat. Ketiganya mempunyai tanggung jawab yang sama dalam pelaksanakan pendidikan. Keluarga merupakan lembaga pendidikan tertua, bersifat informal, pertama dialami oleh anak serta menjadi lembaga pendidikan yang bersifat kodrati sebagai bentuk tanggung jawab orang tua dalam memelihara, melindungi, merawat dan mendidik anak agar tumbuh berkembang dengan baik (Saputro, 2015).

Dari trilogi pendidikan di atas, keluarga menjadi lingkungan pendidikan yang paling mendasar, pertama dan utama. Sadulloh (2010) berpendapat bahwa lingkungan keluarga disebut sebagai lingkungan pendidikan pertama, karena di sinilah anak mengenal dunia pertama kalinya, lingkungan di luar dirinya. Kemudian disebut lingkungan pendidikan yang utama bagi anak, karena keberhasilan pendidikan anak dalam keluarga ketika anak berada dalam usia dini yang dikenal juga sebagai usia emas (golden age), akan sangat berpengaruh pada keberhasilan pendidikan pada periode perkembangan anak berikutnya.

Pernyataan di atas menunjukkan bahwa keluarga sangat berpengaruh dalam kehidupan anak, terutama terkait dengan pendidikan. Keberhasilan pendidikan anak di masa depan tergantung bagaimana pendidikannya di lingkungan keluarga. Orang yang paling berperan dalam pendidikan anak di lingkungan keluarga yaitu orang tua. Orang tua harus mampu menjadi teladan bagi anak dan juga berkewajiban untuk memberikan pendidikan yang layak kepada anak-anaknya.

Orang tua merupakan faktor yang utama dalam belajar anak, Hawadi (2001) menyatakan bahwa partisipasi orang tua terhadap belajar anak merupakan sumbangan yang signifikan pada prestasi yang diraihnya. Hal ini diperkuat oleh penelitian yang dilakukan oleh Bloom terhadap sejumlah profesional muda (usia 28 tahun sampai 35 tahun) yang berhasil dalam kariernya dalam berbagai lapangan seperti pakar matematika, neurolog, pianis maupun olahragawan, menunjukkan ciri-ciri yang sama, yaitu adanya keterlibatan orang tua mereka. Mereka menunjukkan adanya keterlibatan langsung orang tua dalam belajar anak.

Berdasarkan hasil observasi dan wawancara yang dilakukan di SMP Al Irsyad Kota Ternate diketahui bahwa hasil rata-rata nilai UTS mata pelajaran Geografi menunjukan sebanyak 10 orang siswa dari 33 siswa keseluruhan kelas VIII yang belum memenuhi Kriteria Ketuntasan Minimal (KKM). KKM untuk mata pelajaran Geografi adalah 75 .

Berdasarkan pengalaman saat Praktik Pengalaman Lapangan (PPL II) peneliti mencermati perilaku siswa siswi SMP Al-Irsyad yang melebihi batas normal pergaulan anak seusia mereka, saat berada di 
sekolah siswa siswi melakukan perilaku menyimpang seperti bolos sekolah, perkelahian dengan siswa siswi SMP 4 Kota Ternate, merokok saat pulang sekolah, mengkonsumsi lem kastol di sekitaran sekolah dan masih menggunakan seragam sekolah. Hal ini akan sangat mempengaruhi prestasi belajar siswa, oleh karena itu berdasarkan permasalah diatas peneliti tertarik untuk melakukan dengan tujuan penelitian yaitu Untuk mengetahui hubungan antara perhatian orang tua terhadap prestasi belajar siswa dalam bidang studi geografi kelas VIII SMP Al - Irsyad Kota Ternate. Jenis Penelitian yang digunakan dalam penelitian ini adalah penelitian kuantitatif deskriptif, sampel dalam penelitian ini adalah siswa kelas VIII SMP AL-Irsyad Kota Ternate yang berjumlah 33 orang siswa. Teknik dalam pengumpulan data menggunakan kuisioner. kuisioner yang digunkaan telah di uji tingkat validitas dan reabilitas sehingga dapat di distribusikan ke peserta didik. adapun kisikisinya antara lain; memberi bimbingan dan nasehat, pengawasan terhadap anak, memberi penghargaan dan hukuman,pemenuhan fasilitas belajar, menyiapkan suasana rumah yang tenang dan nyaman, dan memberi keteladaan, pengarahan dan ketekunan, dengan analisis data menggunakan rumus korelasi.

\section{Pembahasan}

Sesuai dengan teknik pengumpulan data yaitu menggunakan instrumen angket/quisioner maka hasil pengujian hipotesis menggunakan uji persamaan uji $\mathrm{t}$ dan koefisien korelasi. Selanjutnya data tersebut dianalisis dengan mencari nilai korelasi $\mathrm{X}$ dan $\mathrm{Y}$, hasil yang diperoleh yaitu 0,99 . Untuk nilai korelasi $X$ terhadap $Y$ adalah $>0,75-0,99$ maka dapat disimpulkan bahwa terdapat korelasi yang kuat antara variabel $\mathrm{X}$ terhadap $\mathrm{Y}$. selanjutnya pengujian nilai signifikansi dengan membandingkan $\mathrm{T}_{\text {hitung }}$ dengan $\mathrm{T}_{\text {tabel}}$. Hasil yaitu $\mathrm{T}_{\text {hit }}=39,006$. Dengan kriteria pengujian: jika $T_{\text {hitung }} \geq T_{\text {tabel, }}$ maka signifikan sedangkan jika $\mathrm{T}_{\text {hitung }} \leq \mathrm{T}_{\text {tabel, }}$ maka tidak signifikan. Ternyata $\mathrm{T}_{\text {hitung }} \geq \mathrm{T}_{\text {tabel }}$ atau $39,006>2,039$ dengan $\mathrm{dk}=2$ dan $\mathrm{dk}$ penyebut $=31$, maka dapat disimpulkan bahwa terdapat pengaruh yang signifikan antara perhatian orang tua dengan prestasi belajar siswa kelas VIII pada mata pelajaran Geografi, dan hasil hitungan dari koefisien determinasi yaitu $98 \%$. Berdasarkan hasil perhitungan koefisien determinasi menunjukan hubungan variabel $\mathrm{x}$ terhadap $\mathrm{y}$ sebesar $98 \%$.

Untuk $t_{\text {tebel }}: \mathrm{dk}=\mathrm{n}-2=32-2=31$ pada taraf $\alpha=0,05$. Maka $t_{\text {hit }}>t_{\text {tabel }}$ atau $38,412>2,039$ sehingga $\mathrm{H}_{\mathrm{a}}$ diterima dan $\mathrm{H}_{0}$ ditolak, maka koefisien korelasi adalah signifikan, yang berarti terdapat pengaruh Perhatian Orang Tua Terhadap Prestasi Belajar Siswa dalam Bidang Studi Geografi Siswa Kelas VIII SMP Al-Irsyad Kota Ternate.

Perhatian orang tua yang diberikan dalam bentuk pemberian bimbingan dan nasehat, pengawasan terhadap anak, pemberian penghargaan dan hukuman, 
pemenuhan fasilitas belajar, penciptaan suasana rumah yang tenang, nyaman, dan tentram serta pemberian keteladanan, pengarahan dan dukungan (Pratikno, 2012).

Sejalan dengan pendapat yang dikemukakan oleh Slameto, 2013 dalam (Pintoro, 2015) menyatakan bahwa orang tua yang kurang atau tidak memperhatikan pendidikan anaknya, dapat menyebabkan anak kurang atau tidak berhasil dalam belajarnya. Sementara itu Pintoro (2015) menyatakan bahwa partisipasi orang tua terhadap belajar anak merupakan sumbangan yang signifikan pada prestasi yang diraihnya.

Bentuk Perhatian orang tua dapat dilakukan dengan pemberian bimbingan kepada anak, karena bimbingan dari orang tua anak akan lebih termotivasi dan lebih giat lagi dalam belajar serta mampu memecahkan masalah yang ditemui. Sejalan dengan pendapat oleh Rokhayati, 2014 dalam (Pintoro, 2015) yang menyatakan bahwa ada hubungan antara bimbingan orang tua baik pihak ibu atau pihak ayah terhadap prestasi belajar siswa. Hal ini menunjukakan bahwa salah satu cara untu meningkatkan prestasi belajar siswa didukung dengan perhatian orang tua kepada anak.

Perhatian orang tua juga dapat diberikan dalam bentuk pemberian keteladanan, pengarahan, hal ini diperkuat oleh Safaria (2005) yang mengemukakan bahwa kecerdasan anak tidak dibawa anak sejak lahir namun diperoleh melalui proses belajar yang berkesinambungan, sehingga peran dan perhatian orang tua diperlukan dalam memberikan bimbingan melalui keteladanan dan dukungan terhadap anak.

Pemenuhan fasilitas belajar juga harus mendapat perhatian dari orang tua karena hal tersebut dibutuhkan siswa dalam kegiatan belajar guna meningkatkan prestasi belajar, seperti Pintoro (2015) menjelaskan bahwa fasilitas belajar berpengaruh positif terhadap perstasi belajar siswa, dijelaskan baik fasilitas yang disediakan orang tua di rumah ketika anak belajar dan fasilitas belajar yang tersedia di sekolah.

Pemberian penghargaan dan hukuman yang menjadi indikator perhatian orang tua pun turut berperan dalam peningkatan prestasi belajar siswa, seperti yang dijelaskan oleh Soejono, 1980: dalam (Pintoro, 2015) berpendapat bahwa penghargaan dapat memupuk rasa suka pada perbuatan atau norma yang baik dan memperbesar semangat berbuat luhur. Untuk kegiatan belajar, dengan adanya penghargaan akan membuat anak lebih giat lagi dalam belajar dan berusaha meraih prestasi belajar yang sebaik-baiknya.

Sementara itu dalam pemberian hukuman, Amin, 1973 dalam (Pintoro, 2015) mengatakan bahwa pemberian hukuman harus tetap dalam jalinan cinta kasih sayang. Orang tua dalam memberikan hukuman kepada anak yaitu demi untuk kebaikan, kepentingan, dan masa depan anak. Oleh karena itu, setelah hukuman dilaksanakan maka tidak boleh berakibat putusnya hubungan cinta kasih sayang tersebut. Jadi dalam hal ini orang tua harus lebih bijaksana dalam memberikan pengharagaan maupun hukuman. Dengan demikian, orang tua dan 
pihak sekolah dapat berkomunikasi dengan baik untuk mewujudkan pendidikan anak yang diharapkan.

\section{Kesimpulan}

Hasil penelitian menunjukkan bahwa terdapat hubungan yang positif antara perhatian orang tua terhadap prestasi belajar siswa dalam bidang studi geografi kelas VIII SMP Al-Irsyad Kota Ternate, besar hubungan perhatian orang tua dan prestasi belajar adalah $89 \%$. Semakin tinggi perhatian orang tua maka akan semakin tinggi pula prestasi belajar siswa. Hal ini berarti bentukbentuk perhatian orang tua seperti pemberian bimbingan dan nasehat, pengawasan terhadap anak, pemberian penghargaan dan hukuman, pemenuhan fasilitas belajar, penciptaan suasana rumah yang tenang, nyaman, dan tenteram serta pemberian keteladanan, pengarahan, dan dukungan dapat meningkatkan prestasi belajar dan kecerdasan interpersonal siswa.

\section{Daftar Pustaka}

Hawadi. 2010. Psikologi Perkembangan Anak: Mengenal Sifat, Bakat, dan Kemampuan anak. Jakarta: Grasindo.

Pratikno. 2012. Pengaruh Perhatian Orang Tua Dan Intensitas Belajar Kelompok Terhadap Minat Belajar Siswa Kelas V Sekolah Dasar Negeri Se-Gugus Cahyana Kecamatan Rembang Purbalingga Tahun Pelajaran 2011/ 2012. Skripsi. Yogyakarta: FIP UNY.
Sadulloh, U. 2010. PEDAGOGIK (Ilmu Mendidik). Bandung: Alfabeta.

Safaria. 2005. Interpersonal Intellegence: Metode Pengembangan Kecerdasan Interpersonal anak. Yogyakarta: Amara Books.

Saputro, A.P. 2015. Hubungan Perhatian Orang Tua Terhadap Prestasi Belajar IPS Dan Kecerdasan Interpersonal Siswa SD Kelas III. Skripsi. Universitas Negeri Yogyakarta, Yogyakarta.

Undang-Undang No. 20 Tahun 2003 tentang Sistem Pendidikan Nasional 